\title{
Evaluation of corn steep powder as a protein source of Nile tilapia Oreochromis niloticus diet
}

\section{Evaluasi corn steep powder sebagai sumber protein pada pakan ikan nila Oreochromis niloticus}

\section{Dodi Hermawan', Muhammad Agus Suprayudi ${ }^{*}$, Dedi Jusadi', Alimuddin', Julie Ekasari ${ }^{1}$}

\author{
${ }^{1}$ Department of Aquaculture, Faculty of Fisheries and Marine Science, IPB University, \\ Bogor, West Java 16680, Indonesia \\ *Corresponding author: muhammadsu@apps.ipb.ac.id
}

(Received February 16, 2021; Accepted March 2, 2021)

\begin{abstract}
This study was aimed to evaluate the use of corn steep powder (CSP) as a plant protein source in Oreochromis niloticus diet. A commercial feed with $28 \%$ protein content and $368 \mathrm{kcal} / \mathrm{g}$ energy was used as reference diet, while the test feed consisting of various CSP content, namely $0 \%, 10 \%, 20 \%$, and $30 \%$ and feed containing soybean meal (SBM) at the level of $20 \%$ and $30 \%$. Tilapia were used in the trial with the initial body weight of $6.44 \pm 0.29 \mathrm{~g}$, and reared for thirty days in the aquarium at the density of fifteen and fed 3 times daily at a satiation level. All diets were supplied by $0.5 \%$ of $\mathrm{Cr}_{2} \mathrm{O}_{3}$ as an indicator for digestibility measurement. This study applied the completely randomized design experimental method containing six diet treatments and four replications. The result showed that CSP contains $40.27 \%$ protein, $26.10 \%$ lactic acid, and minerals. CSP is low in crude fiber and anti-nutritional factors. This study results that increasing the level of CSP significantly decreased feed acidity $(\mathrm{P}<0.05)$ compared to the control. The addition of CSP $20 \%$ increased feed digestibility including protein, lipid, energy, and dry matter digestibility. CSP 20\% treatment increased final body weight, specific growth rate and reduced feed conversion ratio significantly $(\mathrm{P}<0.05)$ compared to other treatments. In conclusion, CSP can be used up to $20 \%$ to improve the growth performance of tilapia.
\end{abstract}

Keyword: corn steep powder, feed digestibility, growth performance, tilapia

\begin{abstract}
ABSTRAK
Penelitian ini bertujuan mengevaluasi penggunaan corn steep powder (CSP) sebagai sumber protein nabati pada pakan ikan nila Oreochromis niloticus. Pakan komersial dengan kadar protein $28 \%$ dan energi $368 \mathrm{kkal} / \mathrm{g}$ digunakan sebagai pakan acuan, sementara pakan uji terdiri atas pakan dengan kandungan CSP sebanyak 0\% (CSP0), 10\% (CSP10), 20\% (CSP20) dan 30\% (CSP30) serta pakan dengan kandungan tepung bungkil kedelai (SBM) pada level 20\% (SBM20) dan 30\% (SBM30) sebagai pembanding. Penambahan $\mathrm{Cr}_{2} \mathrm{O}_{3}$ 0,5\% diberikan sebagai indikator untuk mengukur kecernaan. Ikan nila dengan bobot tubuh rata-rata $6.44 \pm 0.29$ dipelihara dalam akuarium $\left(95 \times 45 \times 45 \mathrm{~cm}^{3}\right)$ yang diisi air $100 \mathrm{~L}$ dengan kepadatan 15 ekor per akuarium dan diberi pakan tiga kali sehari secara at satiation selama 30 hari masa pemeliharaan. Penelitian ini menggunakan desain rancangan acak lengkap dengan enam perlakuan dan empat ulangan. Hasil penelitian menunjukkan bahwa CSP mengandung protein sebesar $40,27 \%$, asam laktat 26,10\%, beberapa mineral dan indeks asam amino esensial 0,90. CSP juga rendah serat kasar dan zat antinutrisi. Peningkatan dosis CSP menurunkan $\mathrm{pH}$ pakan secara signifikan $(\mathrm{P}<0,05)$ dibandingkan dengan kontrol. Penambahan CSP sampai level 20\% meningkatkan nilai kecernaan total, kecernaan bahan, kecernaan protein, kecernaan lemak dan kecernaan energi. Di samping itu, perlakuan CSP 20\% meningkatkan bobot akhir, laju pertumbuhan harian dan rasio konversi pakan yang signifikan $(\mathrm{P}<0,05)$ dibandingkan perlakuan lainnya. Hasil penelitian ini menunjukkan bahwa pemberian CSP 20\% dapat meningkatkan kinerja pertumbuhan ikan nila.
\end{abstract}

Kata kunci: corn steep powder, kecernaan pakan, pertumbuhan, ikan nila 


\section{INTRODUCTION}

Feed is the major aspect in supporting the sustainability of aquaculture and it contributes more than 50\% towards the production cost (Ahmad, 2018; Sharma et al., 2014; Collins et al., 2013). The quality and quantity of the feed are the most faced challenges in aquaculture. Feed with a complete nutrition content, i.e., protein, lipid, carbohydrate, mineral, and vitamin, is surely required to support optimal fish growth (Suprayudi et al., 2013). A high-quality feed can be fulfilled through ingredients selection with balanced nutritional content. One of the nutritional aspects that specifically important to be in the feed ingredient and directly determine the cost is protein. Protein is a predominant macronutrient that provides essential and nonessential amino acids, which are later used in protein synthesis and energy in basal metabolism. The energy will be utilized in daily health daily maintenance and growth (Kim et al., 2016; Coloso, 2014). The protein quality is determined by various factors, i.e., amino acid compositions, digestion, absorption, and utilization in the metabolism (Nosworthy \& House, 2017). Since protein could be costly (Mohseni et al., 2013), besides composition, the price tag is one of the considerations in selecting the protein source.

An ingredient will be stated as a potential protein source when it has a particular protein content and amino acids that comply with the requirements of a certain species. Anti nutrition compound is preferably low. For the cost, a relatively low price is still on the top of the list, and sustainability is needed to be maintained (Smiglak-Krajewska, 2020). The most common protein source which is frequently applied in aquaculture is categorized into two different sources, i.e., animal-based and plant-based. The plant-based is more frequently used because of the price, easy access, and the consistency of the nutritional content compared to the animal-based, e.g. fish meal, meat, or poultry by-product (Ayadi et al., 2011). Plant-based protein source from the agriculture by-product that commonly used in the fish feed industry is palm kernel meal (Thongprajukaew et al., 2015; Agbabiaka \& Osuigwe, 2014), dried distiller's grains with solubles (DDGS) (Chatvijitkul et al., 2016; Suprayudi et al., 2015), corn gluten meal (Al-Thobaiti et al., 2018; Potki et al., 2018; Bu et al., 2017; Nandakumar et al., 2017; Herath et al., 2016; Saez et al., 2014), corn steep liquor (Sukhanandi \& Bhatt, 2016), and soybean meal (Bonvini et al., 2018a; Trosvik et al., 2012).

Soybean meal contains $45-53.5 \%$ of protein and $0.5-9 \%$ of lipid (Ahmad et al., 2020; Zhang et al., 2018; Koch et al., 2016; Xu et al. 2016). However, the utilization of soybean meal in aquaculture competes with human needs, the cattle feed industry, and biodiesel production. It causes the high demand, but it is not supported by the sustainable supply which followed the market price (Sekali et al., 2020). Therefore, to guarantee sustainable supply and fish feed production, a substitute protein source should be discovered, especially the protein source that suitable for various aquatic species, easily available, and sustainable supply. These days, most studies about a substitute ingredient lead to waste utilization or agroindustrial by-product. It is believed that we can reduce waste, increase its value, and support the efficiency in natural resource utilization to eliminate the environmental load and support sustainability (Caruso, 2015; Ogello et al., 2014).

One of the discovered potential ingredients as a protein source in fish feed is a corn steep powder (CSP). CSP is the dry form of corn steep liquor (CSL) produced using the spray drying method. CSL comes from the corn starch production waste which contains nitrogen, protein, mineral, vitamin, reducing sugar, organic acid, enzyme, crude fiber-free, phytate acid, and trypsin inhibitor. It also contains anti-nutrition agents, e.g., tannin and saponin (Azizi-Shotorkhoft et al., 2016; Li et al., 2016; Tan et al., 2016; Chovatiya et al., 2011). The result of CSL production reaches 1000 tons/day or 50 tons/day after the changes into CSP (Tereos, 2016). Chovatiya et al. (2011) presented that CSL can substitute the fish meal up to $75 \%$ in Labeo rohita without inhibiting the growth and it can boost the meat quality of Labeo rohita. Nowadays, a specific study about the CSP utilization in aquaculture feed has not existed yet.

This study aimed to evaluate CSP utilization as a plant-based protein source in tilapia Oreochromis niloticus feed. Tilapia was chosen as the experimental fish because of its economic value and it is considered as the future leading species in aquaculture (Yue et al., 2016) with the runner-up worldwide production after carps species (Prabu et al., 2019). It is also the most consumed species in Asia, i.e. China, Indonesia, Taiwan, Thailand, and Malaysia (FAO GLOBEFISH, 2017). 


\section{MATERIALS AND METHODS}

\section{Experimental design}

CSP was obtained from PT. Tereos FKS Indonesia, Cilegon, Banten. Moreover, several tests were conducted towards CSP, i.e., proximate analysis, amino acid, acid detergent fiber (ADF), neutral detergent fiber (NDF), aflatoxin, tannin, saponin, calcium, magnesium, potassium, sodium, phosphorus, chloride, and lactic acid test. A complete randomized design was used in this study, consisted of six treatments with four replications each. Cargill commercial feed (protein $29.51 \%$, lipid $5.27 \%$, ash 13.70 , crude fiber $6.32 \%$, and energy $368 \mathrm{kcal} / \mathrm{g}$ ) was used as reference diet. The experimental feeds were CSP feed $0 \%$ (CSP0), 10\% (CSP10), 20\% (CSP20), and $30 \%$ (CSP30) and soybean meal feed (SBM) $20 \%$ (SBM20) and 30\% (SBM30) as comparator.

\section{Experimental feed}

The experimental feed was produced using commercial feed as a reference diet. CSP was added with different level, namely $0,10 \%, 20 \%$, and $30 \%$. Feed comparator was also made by adding $20 \%$ and $30 \%$ of SBM (Carvalho et al., 2016). The reference diet, which was pellet was crushed and mixed with the other experimental ingredients and $\mathrm{Cr}_{2} \mathrm{O}_{3} \quad 0.5 \%$ (Mmanda, 2020) as the digestibility marker. All ingredients were stirred thoroughly and formed to the pellet (repelleting). After that, the proximate analysis was conducted towards the experimental diet. The formulation of the diet for the digestibility test was presented in Table 1 .

\section{Fish rearing and data collecting}

The experimental tilapia initial weight was $6.44 \pm 0.29$ g. Fish body weight was measured at the beginning and the end of the study. Before rearing, fish was adapted (acclimated) for 7 days. They were reared in 24 aquaria sized in $95 \times 45 \times 45$ $\mathrm{cm}^{3}$ that equipped with a 24-hour aeration system. The stocking density was 15 fish/aquarium. The feeding was delivered three times a day, i.e. $8.00,12.00$, and 16.00 using at satiation feeding method. Feces collecting was started at $4^{\text {th }}$ day after chromium diet feeding (Watanabe, 1988). Feces collection was performed by siphoning an hour after feeding, after that it was placed in a film bottle. The bottle then was stored in $-20^{\circ} \mathrm{C}$ freezer.

\section{Proximate analysis}

The proximate analysis consisted of protein, ash, crude fiber, and water content in CSL, CSP, SBM, feed, and the feces. Protein analysis was done using Kjehdal method. Soxhlet method was applied in lipid analysis, while the $600^{\circ} \mathrm{C}$ furnaces were used to analyze ash. Strong base and strong acid dilution were conducted to analyze crude fiber and water content was analyzed using a furnace at $110^{\circ} \mathrm{C}$ for 4 hours (AOAC, 2005).

Table 1. Experimental feed formulation for CSP digestibility test.

\begin{tabular}{ccccccc}
\hline \multirow{2}{*}{ Ingredient } & \multicolumn{7}{c}{ Diet $(\%)$} \\
\cline { 2 - 7 } & CSP0 & CSP10 & CSP20 & CSP30 & SBM20 & SBM30 \\
\hline Commercial feed & 99.2 & 89.2 & 79.2 & 69.2 & 79.2 & 69.2 \\
CSP & 0 & 10 & 20 & 30 & 0 & 0 \\
SBM & 0 & 0 & 0 & 0 & 20 & 30 \\
PMC & 0.3 & 0.3 & 0.3 & 0.3 & 0.3 & 0.3 \\
Cr$_{2} \mathrm{O}_{3}$ & 0.5 & 0.5 & 0.5 & 0.5 & 0.5 & 0.5 \\
Total & 100 & 100 & 100 & 100 & 100 & 100 \\
\hline Protein & 29.67 & 31.08 & 32.89 & 32.86 & 34.39 & 36.10 \\
Lipid & 4.82 & 6.41 & 5.78 & 5.14 & 5.75 & 5.61 \\
Ash & 10.64 & 12.41 & 13.17 & 14.15 & 12.43 & 11.17 \\
Crude fiber & 7.13 & 6.76 & 6.62 & 5.43 & 5.13 & 5.65 \\
BETN & 47.74 & 43.34 & 41.54 & 42.42 & 42.30 & 41.47 \\
GE (kcal/100 g feed) & 407.19 & 411.97 & 408.80 & 406.24 & 420.05 & 424.90 \\
\hline
\end{tabular}

$\overline{\mathrm{CSP}}=$ corn steep powder; SBM = soybean meal; PMC = polymethylolcarbamide. $\mathrm{CSP} 0=$ reference diet; CSP10 = CSP 10\%; CSP20 = CSP 20\%; CSP30 = CSP 30\%; SBM20 = SBM 20\%; SBM30 = SBM 30\%. BETN= nitrogenfree extract; $\mathrm{GE}=$ gross energy. 


\section{Amino acid analysis}

Amino acid analysis in CSP was done using HPLC (high-performanceliquid chromatography), which consisted of 4 steps, i.e., hydrolysate sample making, drying, derivatization, and amino acid injection (AOAC, 2005).

\section{Mineral analysis}

The observed parameters in CSP were Ferrum, calcium, magnesium, potassium, sodium, and phosphorus using AOAC (2005). Phosphorus analysis was done using a spectrophotometer in a $660 \mathrm{~nm}$ wavelength. Meanwhile, the Ferrum, calcium, magnesium, potassium, and sodium were analyzed using AAS (atomic absorption spectrophotometer) with different wavelengths, i.e. $248.3 \mathrm{~nm}, 422.7 \mathrm{~nm}, 285.2 \mathrm{~nm}, 766.5 \mathrm{~nm}, 589$ $\mathrm{nm}$, respectively.

\section{Digestive enzyme analysis}

The digestive enzyme analysis was conducted on day 30. At the end of the rearing, the fish fasted for 24 hours. As many of 5 fish were collected from each container as samples to be dissected. Digestive enzyme activity was measured from the digestive tract by separating those organs with digestion organs, especially the intestine. The intestine was collected and homogenized (40 mg of tissue $/ \mathrm{mL}$ ) in $0.15 \mathrm{M} \mathrm{NaCl}$. The result of the preparation was centrifuged in $10000 \times \mathrm{g}$ for 10 minutes at $4{ }^{\circ} \mathrm{C}$. The sample was diluted ten times in aquadest to obtain the crude enzyme ex tract to be stored in a $-20^{\circ} \mathrm{C}$ freezer until the analysis started. Protease enzyme was measured using casein as a substrate and tyrosine as the standard (Bergmeyer et al., 1983). Lipase activity was analyzed using plant-based oil as the substrate (Linfield et al., 1984). Amylase activity was measured using starch as the substrate and maltose as the standard (Bernfield, 1955). Meanwhile, the pepsin was analyzed using Worthington (1993) method, and trypsin and chymotrypsin was analyzed using a method by Erlanger et al. (1961)

\section{Digestibility analysis}

The feces were collected 4 days after the experimental feeding (Watanabe, 1988). The $\mathrm{Cr}_{2} \mathrm{O}_{3}$ measurement in the experimental diet and feces were managed by drying the sample and the absorbent interpretation on spectrophotometer was done using $350 \mathrm{~nm}$ of wavelength (Takeuchi, 1988).

\section{The pH measurement of experimental diet and digestion tract}

The $\mathrm{pH}$ measurement was done by mixing 5 $\mathrm{g}$ of experimental diet into $50 \mathrm{~mL}$ of aqua dest and stirring the mixture using a magnetic stirrer for 1 minute ( $\mathrm{Li}$ et al., 2015). The gastric $\mathrm{pH}$ measurement was conducted two hours after feeding, while the intestine $\mathrm{pH}$ level was measured six hours after feeding (Castillo et al., 2014). The remaining fish diet in the gastric and intestine as many as $5 \mathrm{~g}$ was diluted in the $50 \mathrm{~mL}$ of aqua dest (Li et al., 2015). The $\mathrm{pH}$ level of the diet, gastric, and intestine were measured using a $\mathrm{pH}$ meter.

\section{The growth and digestion performance analysis}

The digestion performance was calculated based on Takeuchi (1988), including total digestibility, ingredient, protein, lipid, and energy digestibility. The total digestibility was calculated using the total digestibility $(\%)=[1-$ a/a'] $\times 100$, with a is the $\mathrm{Cr}_{2} \mathrm{O}_{3}$ concentration in the experimental diet and a' is the $\mathrm{Cr}_{2} \mathrm{O}_{3}$ concentration in the feces. The ingredient digestibility was calculated using the formula: ingredient digestibility $(\%)=[[$ ADT $-0.7 \times$ $\mathrm{AD}] / 0.3] \times 100$, with $\mathrm{ADT}$ as the total ingredient digestibility and $\mathrm{AD}$ as the total digestibility of the reference diet. The protein and lipid digestibility were calculated using the following formula: nutrient digestibility $(\%)=\left[1-\mathrm{a} / \mathrm{a}^{\prime} \times \mathrm{b}^{\prime} / \mathrm{b}\right]$ $\times 100$, with a is the $\mathrm{Cr}_{2} \mathrm{O}_{3}$ concentration in the experimental diet, a' is the $\mathrm{Cr}_{2} \mathrm{O}_{3}$ concentration in the feces, $b$ is the nutrient compound the fish diet, and b' is the nutrient compound in the feces. The digested energy was calculated using the following formula: digested energy $=\mathrm{Ep}-\mathrm{Ef} \times$ $[\mathrm{n} / \mathrm{n}$ '], with Ep is diet energy, Ef is feces energy, $\mathrm{n}$ is the $\mathrm{Cr}_{2} \mathrm{O}_{3}$ concentration in the experimental diet, and n' is the $\mathrm{Cr}_{2} \mathrm{O}_{3}$ concentration in the feces. The energy digestibility was calculated through this formula: energy digestibility $(\%)=$ [digested energy/energy diet] $\times 100$.

The essential amino acids index (IAAE) was calculated according to Kirimi et al. (2020), i.e. $\mathrm{IAAE}=($ aa $1 / \mathrm{AA} 1) \times($ aa2$/ \mathrm{AA} 2) \times \ldots \times($ aan $/$ AAn $)^{1 / n}$, with aal is the essential amino acid in the experimental diet, AA is the essential amino acid required by the fish, and $\mathrm{n}$ is the amount of evaluated essential amino acid. The survival rate was calculated by dividing the final population and initial population then changed it into a percentage. 
The growth performance was measured at the end of the study (day 30). The measured parameters were feed consumption, specific growth rate (SGR), and feed conversion ratio (FCR). Feed consumption was calculated using: feed consumption $(\mathrm{g} / \mathrm{fish})=\left[\sum\right.$ consumed diet $/ \sum$ final population]. SGR was calculated using: SGR $(\% /$ day $)=[\mathrm{Ln} \mathrm{Wt}-\mathrm{Ln} \mathrm{Wo}] / \mathrm{T} \times 100$, with Wt is the final average weight, Wo is the initial average weight, and $\mathrm{T}$ is the rearing period. FCR was calculated using: $\mathrm{FCR}=\mathrm{F} /[\mathrm{Wt}-\mathrm{Wo}], \mathrm{Wt}$ is the final fish biomass and Wo is the initial biomass.

Table 2. Proximate composition, antinutritional compound, and mineral in CSP.

\begin{tabular}{|c|c|c|c|}
\hline & CSP & $\mathrm{CSL}^{\mathrm{a}}$ & $\mathrm{SBM}^{\mathrm{b}}$ \\
\hline Water content & 5.13 & 22.75 & 11.92 \\
\hline Protein $(\%)$ & 40.27 & 43.48 & 44.02 \\
\hline Ash $(\%)$ & 22.92 & 10.30 & 6.34 \\
\hline Lipid (\%) & 0.82 & 0.10 & 1.79 \\
\hline Crude fiber (\%) & 0.30 & 0 & 6.26 \\
\hline $\begin{array}{l}\text { Total energy } \\
(\mathrm{kcal} / 100 \mathrm{~g})\end{array}$ & 296.42 & 379.00 & 416.50 \\
\hline Lactic acid (\%) & 26.10 & 20.79 & $2.38^{\mathrm{g}}$ \\
\hline $\mathrm{pH}$ & 5.62 & 4.70 & - \\
\hline Starch $(\%)$ & $<10$ & - & 5.51 \\
\hline Reducing sugar (\%) & 0.12 & 2.76 & - \\
\hline $\begin{array}{l}\text { Acid detergent fiber } \\
(\%)\end{array}$ & 0.22 & 0 & 8.76 \\
\hline $\begin{array}{l}\text { Neutral detergent fibre } \\
(\%)\end{array}$ & 0.52 & 0 & 13.05 \\
\hline \multicolumn{4}{|c|}{ Antinutrition compound } \\
\hline Aflatoxin $(\mu \mathrm{g} / \mathrm{g})$ & ND & ND & $1.30^{\mathrm{c}}$ \\
\hline Phytate acid (mg/g) & ND & ND & $1,16^{\mathrm{d}}$ \\
\hline Tanin (mg/g) & 0.03 & 0.48 & $1.93^{\mathrm{d}}$ \\
\hline $\begin{array}{l}\text { Trypsin inhibitor } \\
\text { (TIU/g) }\end{array}$ & ND & ND & $1.20^{\mathrm{d}}$ \\
\hline Saponin $(\mathrm{mg} / \mathrm{g})$ & 0.92 & 0.87 & $0.60^{\mathrm{e}}$ \\
\hline \multicolumn{4}{|l|}{ Mineral (\%) } \\
\hline Ferrum $(\mathrm{Fe})$ & 0.2 & 0.02 & $0.01^{\mathrm{f}}$ \\
\hline Calcium (Ca) & 0.05 & 0.08 & $0.31^{\mathrm{f}}$ \\
\hline Magnesium (Mg) & 2.21 & 0.58 & $0.27^{\mathrm{f}}$ \\
\hline Potassium (K) & 4.86 & 2.94 & $1.99^{\mathrm{f}}$ \\
\hline Sodium (Na) & 1.12 & - & $0.02^{\mathrm{f}}$ \\
\hline Phosphorus (P) & 3.15 & 1.60 & - \\
\hline 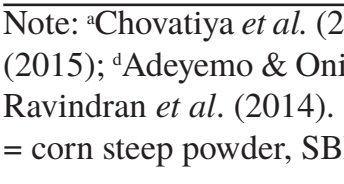 & $\mathrm{L}=\mathrm{co}$ & 2012); ${ }^{c 1}$ & $\begin{array}{l}\text { aga et al. } \\
(2001) \text {; } \\
\text { uor, CSP }\end{array}$ \\
\hline
\end{tabular}

\section{Data analysis}

The survival rate, specific growth rate (SGR), FCR, total digestibility, protein, lipid, energy, and ingredients digestibility, feed $\mathrm{pH}$, digestive tract $\mathrm{pH}$, and enzyme activity were analyzed using one-way ANOVA with a 95\% confidence level and were further tested using Duncan's test. Statistical analysis was conducted using SPSS 24.

\section{RESULTS AND DISCUSSION}

\section{Result}

\section{CSP composition}

Proximate composition, mineral content, and antinutritional compound in CSP was shown in Table 2. The CSP had $40.27 \%$ protein and antinutritional compound, such as aflatoxin, phytate acid, and trypsin inhibitor, was not found. CSP was relatively acid with lactic acid levels up to $26.10 \%$. CSP contained several minerals, i.e. Ferrum, calcium, magnesium, potassium, sodium, and phosphorus. Amino acid composition in CSP

Table 3. Amino acid and essential amino acid index in CSP and SBM.

\begin{tabular}{lcc}
\hline \multicolumn{1}{c}{ Amino acid } & CSP & SBM $^{* a}$ \\
\hline \multicolumn{2}{l}{ Essential amino acid $(\boldsymbol{\%})$} & \\
Lysine & 2.02 & 2.7 \\
Methionine & 0.62 & 0.68 \\
Histidine & 1.91 & 1.1 \\
Threonine & 1.34 & 1.79 \\
Arginine & 0.92 & 2.82 \\
Leucine & 2.66 & 3.27 \\
Valine & 2.23 & 2.07 \\
Isoleucine & 1.16 & 2.2 \\
Phenylalanine & 1.19 & 1.37 \\
Tryptophan & 0.16 & 0.6 \\
EAA total & 14.21 & 18.6 \\
EAAI & 0.90 & 0.95 \\
Non essential amino acid (\%) & \\
Aspartic acid & 1.78 & 6.27 \\
Serine & 1.61 & 2.25 \\
Glutamic acid & 4.4 & 10.26 \\
Glycine & 1.99 & 1.98 \\
Alanine & 3.14 & 1.98 \\
Cystine & 1.07 & 0.74 \\
Tyrosine & 0.68 & 1.56 \\
\hline
\end{tabular}

Note: $\mathrm{CSP}=$ corn steep powder; SBM=soybean meal; $\mathrm{EAAI}=$ essential amino acid index; $\mathrm{a}=$ amino acid composition data of SBM from IAFFD (2020). 
Table 4. Feed $\mathrm{pH}$, gastric $\mathrm{pH}$, and intestine $\mathrm{pH}$ of tilapia

\begin{tabular}{ccccccc}
\hline \multirow{2}{*}{ Parameter } & \multicolumn{5}{c}{ Treatment } \\
\cline { 2 - 7 } & CSP0 & CSP10 & CSP20 & CSP30 & SBM20 & SBM30 \\
\hline Feed pH & $5.58 \pm 0.03^{\mathrm{e}}$ & $5.44 \pm 0.02^{\mathrm{c}}$ & $5.37 \pm 0.01^{\mathrm{b}}$ & $5.33 \pm 0.00^{\mathrm{a}}$ & $5.53 \pm 0.02^{\mathrm{d}}$ & $5.72 \pm 0.02^{\mathrm{f}}$ \\
Gastric pH & $4.67 \pm 0.04^{\mathrm{c}}$ & $4.63 \pm 0.13^{\mathrm{c}}$ & $4.40 \pm 0.06^{\mathrm{b}}$ & $4.25 \pm 0.09^{\mathrm{a}}$ & $4.25 \pm 0.02^{\mathrm{a}}$ & $4.14 \pm 0.10^{\mathrm{a}}$ \\
Intestine pH & $7.01 \pm 0.06^{\mathrm{a}}$ & $7.17 \pm 0.08^{\mathrm{c}}$ & $7.26 \pm 0.06^{\mathrm{d}}$ & $7.04 \pm 0.06^{\mathrm{ab}}$ & $7.12 \pm 0.03^{\mathrm{bc}}$ & $7.13 \pm 0.13^{\mathrm{cd}}$ \\
\hline
\end{tabular}

Note: CSP0 $=$ reference diet; CSP10=CSP 10\%; CSP20=CSP 20\%; CSP30=CSP 30\%; SBM20=SBM 20\%; SBM30=SBM 30\%. Different superscript in the same row indicated significant differences $(\mathrm{P}<0.05)$.

Table 5. Digestive enzyme activity in tilapia fed with various corn steep powder content after 30 days of rearing.

\begin{tabular}{ccccccc}
\hline \multirow{2}{*}{ Parameter } & \multicolumn{5}{c}{ Treatment } \\
\cline { 2 - 6 } & CSP0 & CSP10 & CSP20 & CSP30 & SBM20 & SBM30 \\
\hline $\begin{array}{c}\text { Amylase } \\
\text { (IU/mL) }\end{array}$ & $2.19 \pm 0.15$ & $2.45 \pm 0.32$ & $2.64 \pm 0.30$ & $2.25 \pm 0.13$ & $2.03 \pm 0.53$ & $2.33 \pm 0.13$ \\
$\begin{array}{c}\text { Lipase } \\
\text { (IU/mL) }\end{array}$ & $0.25 \pm 0.01^{\mathrm{a}}$ & $0.26 \pm 0.01^{\mathrm{bc}}$ & $0.27 \pm 0.01^{\mathrm{c}}$ & $0.24 \pm 0.01^{\mathrm{a}}$ & $0.25 \pm 0.01^{\mathrm{ab}}$ & $0.26 \pm 0.01^{\mathrm{bc}}$ \\
$\begin{array}{c}\text { Protease } \\
\text { (IU/mL) }\end{array}$ & $0.11 \pm 0.01^{\mathrm{a}}$ & $0.13 \pm 0.01^{\mathrm{b}}$ & $0.22 \pm 0.01^{\mathrm{e}}$ & $0.12 \pm 0.02^{\mathrm{ab}}$ & $0.16 \pm 0.01^{\mathrm{c}}$ & $0.19 \pm 0.01^{\mathrm{d}}$ \\
$\begin{array}{c}\text { Trypsin } \\
(\mathrm{IU} / \mathrm{mL})\end{array}$ & $0.03 \pm 0.01^{\mathrm{b}}$ & $0.02 \pm 0.00^{\mathrm{a}}$ & $0.05 \pm 0.01^{\mathrm{c}}$ & $0.03 \pm 0.00^{\mathrm{b}}$ & $0.03 \pm 0.00^{\mathrm{b}}$ & $0.03 \pm 0.00^{\mathrm{b}}$ \\
$\begin{array}{c}\text { Chymotrypsin } \\
(\mathrm{IU} / \mathrm{mL})\end{array}$ & $0.0010 \pm 0.00$ & $0.0007 \pm 0.00$ & $0.0007 \pm 0.00$ & $0.0007 \pm 0.00$ & $0.0007 \pm 0.00$ & $0.0008 \pm 0.00$ \\
$\begin{array}{c}\text { Pepsin } \\
(\mathrm{IU} / \mathrm{mL})\end{array}$ & $0.091 \pm 0.00^{\mathrm{a}}$ & $0.102 \pm 0.00^{\mathrm{c}}$ & $0.123 \pm 0.00^{\mathrm{d}}$ & $0.091 \pm 0.00^{\mathrm{ab}}$ & $0.093 \pm 0.00^{\mathrm{b}}$ & $0.093 \pm 0.00^{\mathrm{b}}$ \\
Ratio T: C & $36.65 \pm 14.10^{\mathrm{b}}$ & $21.16 \pm 1.91^{\mathrm{a}}$ & $70.50 \pm 13.32^{\mathrm{c}}$ & $38.77 \pm 3.84^{\mathrm{b}}$ & $42.62 \pm 10.61^{\mathrm{b}}$ & $44.79 \pm 1.65^{\mathrm{b}}$ \\
\hline
\end{tabular}

Note: CSP0=reference diet; CSP10=CSP 10\%; CSP20=CSP 20\%; CSP30=CSP 30\%; SBM20=SBM 20\%; SBM30=SBM 30\%. Ratio T: $\mathrm{C}=$ trypsin: chymotrypsin ratio; Different superscript in the same row indicated significant differences $(\mathrm{P}<0.05)$.

Table 6. Experimental diet digestibility with various CSP content in tilapia.

\begin{tabular}{|c|c|c|c|c|c|c|}
\hline \multirow{2}{*}{ Parameters } & \multicolumn{6}{|c|}{ Treatments } \\
\hline & CSP0 & CSP10 & CSP20 & CSP30 & SBM20 & SBM30 \\
\hline $\begin{array}{c}\text { Total } \\
\text { digestibility } \\
(\%)\end{array}$ & $67.87 \pm 1.90^{\mathrm{a}}$ & $69.232 \pm 0.12^{\mathrm{b}}$ & $73.43 \pm 0.16^{\mathrm{d}}$ & $69.53 \pm 0.30^{\mathrm{b}}$ & $70.49 \pm 0.13^{\mathrm{b}}$ & $72.16 \pm 0.46^{c}$ \\
\hline $\begin{array}{l}\text { Ingredient } \\
\text { digestibility } \\
(\%)\end{array}$ & - & $81.47 \pm 1.16^{b}$ & $95.64 \pm 0.80^{c}$ & $73.40 \pm 0.98^{\mathrm{a}}$ & $80.97 \pm 0.63^{b}$ & $82.15 \pm 1.52^{b}$ \\
\hline $\begin{array}{c}\text { Protein } \\
\text { digestibility } \\
(\%)\end{array}$ & $85.78 \pm 0.87^{\mathrm{a}}$ & $87.95 \pm 0.95^{b}$ & $89.17 \pm 0.42^{\mathrm{c}}$ & $85.99 \pm 0.87^{\mathrm{a}}$ & $88.12 \pm 0.32^{\mathrm{b}}$ & $90.62 \pm 0.40^{d}$ \\
\hline $\begin{array}{c}\text { Lipid } \\
\text { digestibility } \\
(\%)\end{array}$ & $81.98 \pm 0.54^{a}$ & $86.22 \pm 0.56^{c}$ & $87.98 \pm 0.35^{\mathrm{d}}$ & $83.80 \pm 1.29^{b}$ & $85.69 \pm 0.61^{\mathrm{c}}$ & $88.04 \pm 1.21^{\mathrm{d}}$ \\
\hline $\begin{array}{c}\text { Energy } \\
\text { digestibility } \\
(\%)\end{array}$ & $78.68 \pm 1.10^{\mathrm{a}}$ & $81.17 \pm 0.54^{b}$ & $84.28 \pm 0.35^{\mathrm{d}}$ & $82.51 \pm 0.23^{c}$ & $81.20 \pm 0.10^{\mathrm{b}}$ & $84.08 \pm 0.51^{\mathrm{d}}$ \\
\hline
\end{tabular}


and SBM were presented in Table 3. Valine and histidine in CSP were higher than SBM. IAAE level in CSP was lower than SBM.

\section{Digestion activity}

Feed, intestine, and gastric $\mathrm{pH}$ levels were presented below in Table 4. The $\mathrm{pH}$ level in the experimental feed showed a higher result in CSP0 and SBM compared to CSP10, CSP20, and CSP30 $(\mathrm{P}<0.05)$. The lowest $\mathrm{pH}$ level in the tilapia gastric was found in CSP30 $(\mathrm{P}<0.05)$. On the contrary, the CSP20 treatment presented a higher $\mathrm{pH}$ level than the other treatments $(\mathrm{P}<0.05)$.

Amylase, lipase, protease, pepsin, chymotrypsin, and trypsin activity were described in Table 5. It was shown that protease, trypsin, and pepsin activity in CSP20 treatment was higher than the others $(\mathrm{P}<0.05)$. Meanwhile, the amylase and chymotrypsin did not show a significant difference amongst treatments $(\mathrm{P}>0.05)$.
The diet/feed digestibility consisted of total, protein, lipid, and energy digestibility. Those existed in Table 6. The total digestibility was higher in CSP and SBM treatment compared to the control. The CSP20 resulted in the highest ingredients and total digestibility compared with the other treatments $(\mathrm{P}<0.05)$. Lipid and energy digestibility in the CSP20 was the same as in the SBM30 $(\mathrm{P}>0.05)$, but higher than the CSP0, CSP10, CSP30, and SBM20 $(\mathrm{P}<0.05)$.

\section{Growth performance}

Feed consumption increased along with the CSP existence in the experimental diet. The CSP30 presented a higher feed consumption than the other treatments $(\mathrm{P}<0.05)$ (Table 7$)$. The final weight and SGR in the CSP20 were higher than the rest of the treatments $(\mathrm{P}<0.05)$. The survival rate $(\mathrm{SR})$ in all treatments exhibited a similar result, i.e. $100 \%(\mathrm{P}<0.05)$.

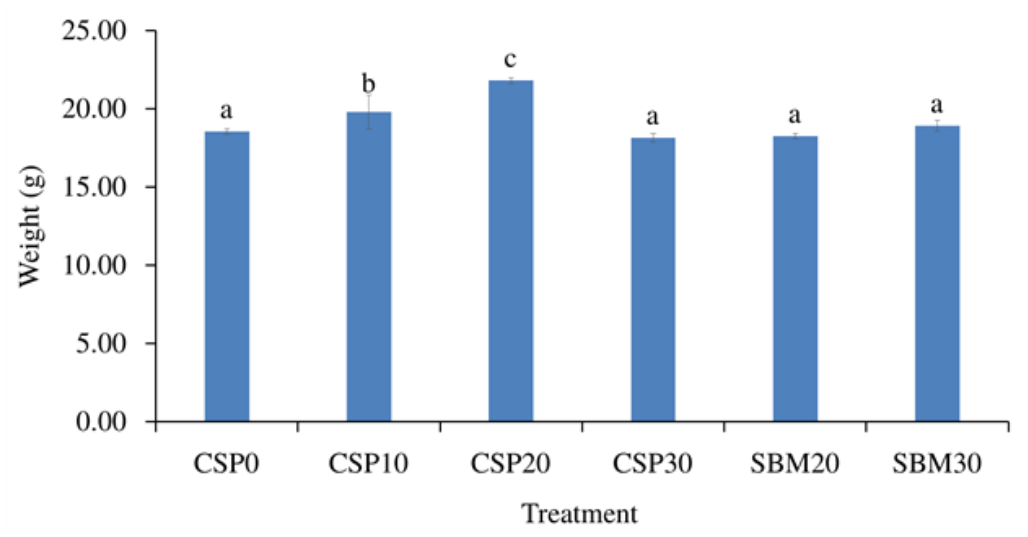

Figure 1. The final weight of tilapia Oreochromis niloticus during the rearing period. Different superscript in the same row indicated significant differences $(\mathrm{P}<0.05)$.

Table 7. Growth performance of Nile tilapia fed with different corn steep powder content.

\begin{tabular}{|c|c|c|c|c|c|c|}
\hline \multirow{2}{*}{ Parameters } & \multicolumn{6}{|c|}{ Treatments } \\
\hline & CSP0 & CSP10 & CSP20 & CSP30 & SBM20 & SBM30 \\
\hline $\begin{array}{l}\text { Initial weight } \\
\qquad(\mathrm{g})\end{array}$ & $6.50 \pm 0.08^{b}$ & $6.43 \pm 0.08^{b}$ & $6.42 \pm 0,04^{\mathrm{ab}}$ & $6.50 \pm 0.04^{b}$ & $6.36 \pm 0.03^{\mathrm{a}}$ & $6.43 \pm 0.04^{\mathrm{ab}}$ \\
\hline Final weight (g) & $18.56 \pm 0.16^{\mathrm{a}}$ & $19.82 \pm 1.08^{b}$ & $21.83 \pm 0.18^{c}$ & $18.16 \pm 0.28^{\mathrm{a}}$ & $18.26 \pm 0.17^{\mathrm{a}}$ & $18.92 \pm 0.35^{\mathrm{a}}$ \\
\hline $\begin{array}{c}\text { Feed } \\
\text { consumption }(\mathrm{g})\end{array}$ & $248 \pm 13.76^{\mathrm{a}}$ & $249 \pm 6.05^{\mathrm{a}}$ & $259 \pm 7.96^{\mathrm{ab}}$ & $276 \pm 6.99^{c}$ & $264 \pm 1.66^{b}$ & $258 \pm 4.23^{\mathrm{ab}}$ \\
\hline $\begin{array}{l}\text { Individual feed } \\
\text { consumption } \\
\text { (g/fish) }\end{array}$ & $16.59 \pm 0.92^{\mathrm{a}}$ & $16.63 \pm 0.40^{\mathrm{a}}$ & $17.27 \pm 0.53^{\mathrm{ab}}$ & $18.42 \pm 0.47^{\mathrm{c}}$ & $17.65 \pm 0.11^{b}$ & $17.22 \pm 0.28^{\mathrm{ab}}$ \\
\hline FCR & $1.39 \pm 0.05^{\mathrm{cd}}$ & $1.25 \pm 0.13^{\mathrm{b}}$ & $1.12 \pm 0.04^{\mathrm{a}}$ & $1.58 \pm 0.05^{\mathrm{e}}$ & $1.48 \pm 0.02^{\mathrm{de}}$ & $1.38 \pm 0.02^{\mathrm{c}}$ \\
\hline SGR (\%/day) & $3.50 \pm 0.07^{\mathrm{ab}}$ & $3.63 \pm 0.08^{\mathrm{d}}$ & $3.71 \pm 0.04^{\mathrm{e}}$ & $3.43 \pm 0.04^{\mathrm{a}}$ & $3.52 \pm 0.01^{\mathrm{bc}}$ & $3.60 \pm 0.07^{\mathrm{cd}}$ \\
\hline $\operatorname{SR}(\%)$ & 100 & 100 & 100 & 100 & 100 & 100 \\
\hline
\end{tabular}




\section{Discussion}

The protein content in CSP was lower than CSL and SBM, but it was higher than the other plant-based protein from agro-industrial byproducts, such as DDGS (distillers dried grains with solubles) 28.90-31.30\% (Magalhaes et al., 2015; Welker et al., 2014), corn gluten feed 21.40-28.70\% (IAFFD, 2020), oilseed meal $17.81 \%$ (Obirikorang et al., 2015), rubber seed meal 25.40\% (Sharma et al., 2014), and raw kapok Ceiba pentandra seed meal 20-35\% (Wafar et al., 2017). CSP contains a lower level of acid detergent fiber (ADF), neutral detergent fiber (NDF), and crude fiber compared to the SBM. Crude fiber is still needed, although it is hardly digested. The low level of crude fiber increased peristaltic movement, thus the digestion process and chemical degradation rate of the diet increased as well (Pandey, 2013; Manullang et al., 2018). The crude fiber level in the tested diet was lower than $15.5 \%$, but it still supported the growth and health performance of the fish (Bonvini et al., 2018b). The essential amino acids in CSP showed that this particular ingredient was applicable as a protein source for tilapia. A feed ingredient is categorized feasible as a protein source if it hit
0.9 of the essential amino acid indices. A 0.8 level will be classified as a beneficial protein source and 0.7 will be considered as incomplete (Bunda et al., 2015).

A plant-based protein source exploitation as an alternative ingredient of fish diet frequently obstructed by the antinutritional compound. An excessive level of the antinutritional compound will directly affect nutrient intake and digestibility (Bandara, 2018). CSP is an antinutritionalfree compound, such as phytate acid, aflatoxin, and trypsin inhibitor. The low level of the antinutritional compound in CSP indicates a fermentation activity by Lactobacillus sp. during the submersion process. Lactic acid fermentation can reduce phytate acid, thus the antinutritional compound in CSP is low (Roger et al., 2015; Rahimi et al., 2017).

CSP addition in fish diet influenced feed, gastric, and intestinal $\mathrm{pH}$ differently related to the lactic acid existence in CSP. CSP contains lactic acid higher than CSL. Organic acid content, especially lactic acid, arises from the corn fermentation by lactic acid bacteria in the corn starch industry (Ni et al., 2017). Lactic acid is reported to be involved in the glycolytic process

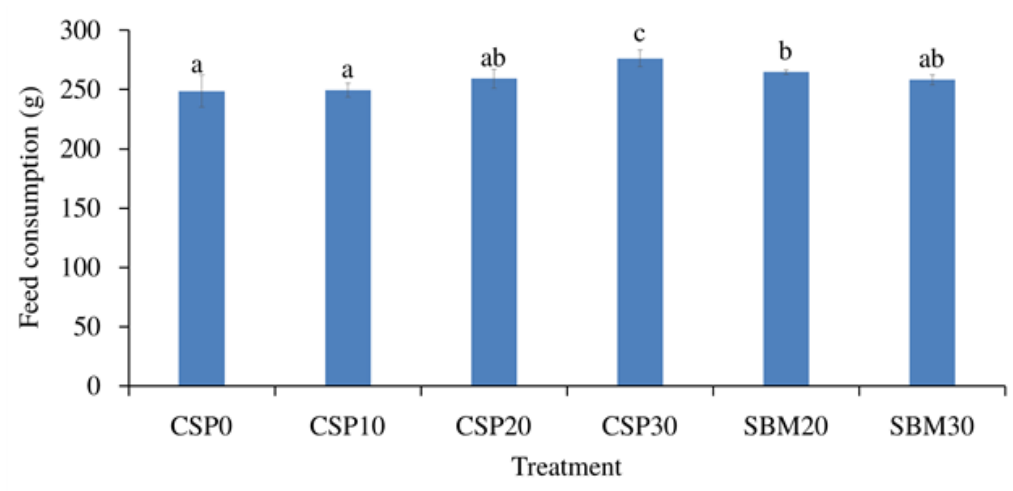

Figure 2. Feed consumption of tilapia Oreochromis niloticus during the rearing period. Different superscript in the same row indicated significant differences $(\mathrm{P}<0.05)$.

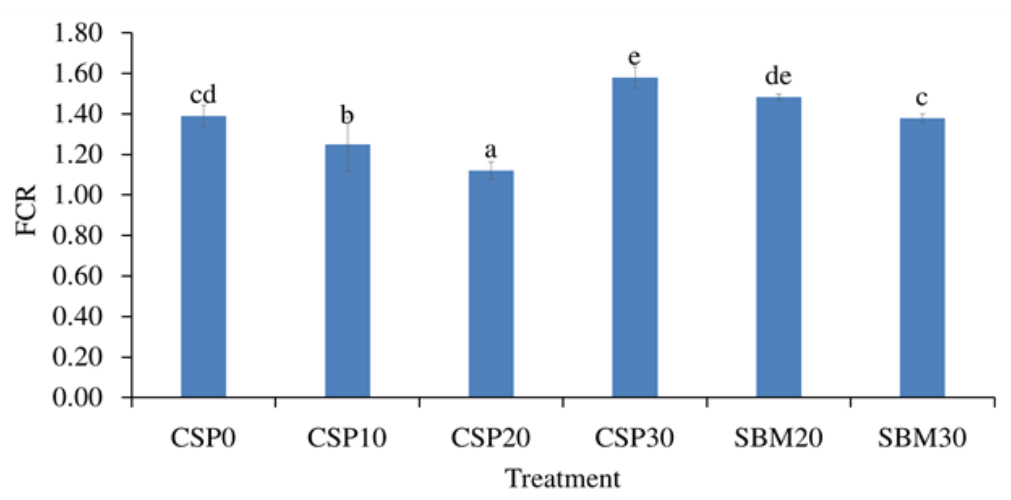

Figure 3. Feed convertion ratio (FCR) of tilapia Oreochromis niloticus during the rearing period. Different superscript in the same row indicated significant differences $(\mathrm{P}<0.05)$. 
because it is known that the quality and quantity of the carbohydrate impacted glycolytic enzyme, such as hexokinase on fish species (Sun et al., 2017). The organic acid's role in the digestion tract involved two mechanisms, i.e. decreasing $\mathrm{pH}$ level in the gastric, especially in the small intestine, through $\mathrm{H}^{+}$transfer and inhibiting Gramnegative bacteria growth through acid dissociation and anion production in the bacteria cell (Castillo et al., 2014; Hamidah et al., 2019). Lactic acid bacteria in the fish intestine have a certain mechanism to balance the microbe population. Thus, the digestibility will be increased. It is managed by converting the carbohydrate through an enzymatic reaction into lactic acid that can lower pH levels (Setyawan et al., 2014). It is in line with Castillo et al. (2014) who stated that the citric acid administration can reduce $\mathrm{pH}$ levels in the gastric from 4.48 to 4.37 .

The enzyme activity in the digestive tract is an indicator of digestibility and the ability to utilize the nutrient in the fi'ssh diet. This study showed that CSP0, CSP10, and CSP20 could not inhibit the protease enzyme activity. It was supported by a former study on CSL which reported that protease enzyme activity increased up to $50 \%$ of
CSL (Chovatiya et al., 2011). In addition, trypsin inhibitor is not found in the CSP, because of the existence of antinutritional factor (ANF) which can block the trypsin activity (Lima et al., 2019). The acid environment in the gastric is related to the higher activity of pepsin that contributes to boosting protein digestibility (Marquez et al., 2012). Several studies used trypsin and chymotrypsin ratio (T: C) as a growth indicator (Rungruangsak-Torrissen \& Monoonpong, 2019; Chamchuen et al., 2014). In this study, the highest ratio of trypsin and chymotrypsin was in CSP20 treatment and it correlated to the increase of growth performance. Trypsin and chymotrypsin are major digestion enzymes secreted in the anterior part of the intestine. Trypsin hydrolyzes the peptide bond in the carboxyl side of amino acid. Meanwhile, chymotrypsin hydrolyzes the peptide bond in the aromatic amino acid (Moraes \& Almeida, 2020). The impact of the endopeptidase activity combination generates a micro protein and peptide fragments on the intestine. Furthermore, hydrolysis is conducted by the exopeptidase secreted by the pancreatic and enterocyte apical membrane. Peptidase in the enterocyte membrane contributes to the final

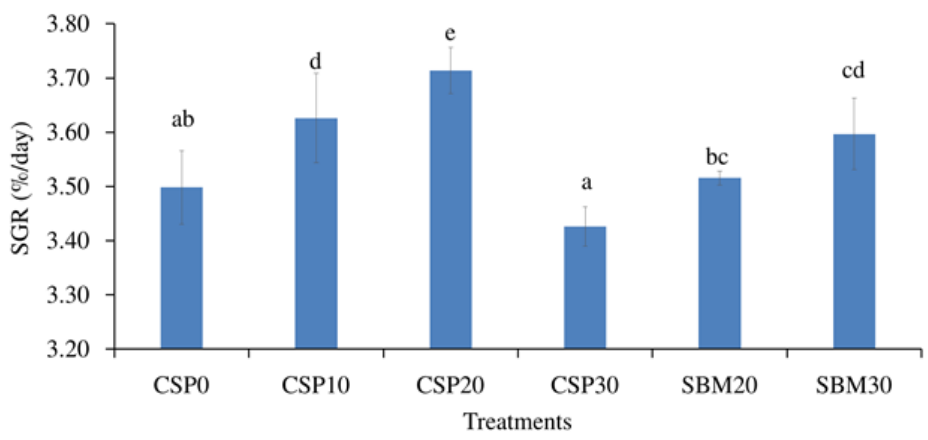

Figure 4. Specific growth rate (SGR) of tilapia Oreochromis niloticus during the rearing period. Different superscript in the same row indicated significant differences $(\mathrm{P}<0.05)$.

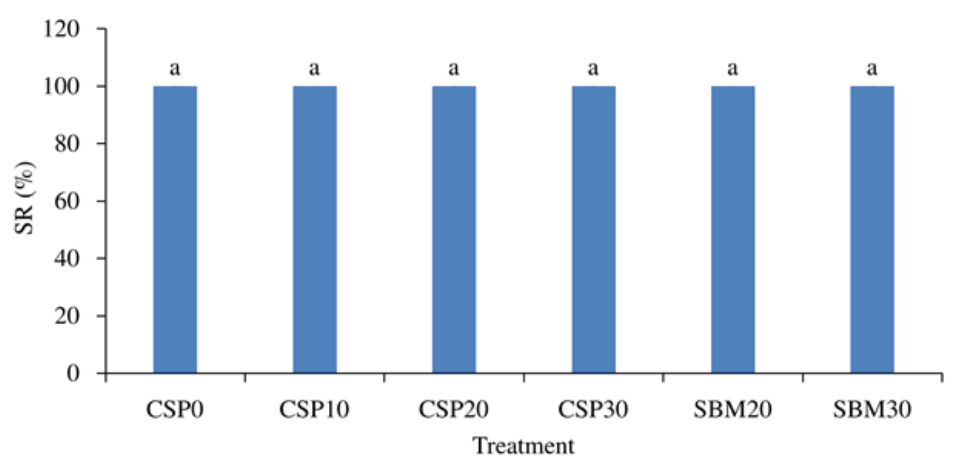

Figure 5. Survival rate (SR) of tilapia Oreochromis niloticus during the rearing period. Different superscript in the same row indicated significant differences $(\mathrm{P}<0.05)$. 
result of the digestion, in form of micropeptide and free amino acid that is easily digested by the intestine. A higher T: $\mathrm{C}$ ratio is frequently related to the essential amino acid absorption for protein synthesis and growth performance (Ronnestad et al., 2013). Trypsin and chymotrypsin can be used as nutrition indicator of an organism because it represents proteolytic enzyme activity in protein synthesis as a major component in fish diet (Liu et al., 2011; Yulintine et al., 2012).

Digestibility describes the quantity of digestible and absorbable nutrients to support metabolism and growth. A certain ingredient digestibility is influenced by the processing method, life phase, ingredient quality, diet size, and fish activity (Suprayudi et al., 2012). Protein digestibility increases along with the CSP20 dosage, but it decreases on CSP30 treatment. It is supported by Chovatiya (2011) who stated that the CSL administration in 25-75\% resulted from protein digestibility $89.10-90.87 \%$. The high percentage of protein digestibility could be caused by the low crude fiber content and a high protease enzyme activity which degrades protein so that it facilitates easier peristaltic movement and nutrient absorption (Suprayudi et al., 2012; Manullang et al., 2018). Nonetheless, protein digestibility in all treatments was in a tolerable range of around $75-95 \%$ (NRC, 2011).

The CSP addition of an inclusive level of $30 \%$ in the fish diet reduces lipid digestibility. It was assumed that the saponin compound in the CSP was higher than in the SBM. SBM addition in fish diet could lower the lipid digestibility in greater amberjack Seriola dumerili juvenile (Dawood et al., 2015). Saponin content in the CSP inhibits bile salt absorption. It is matched with the study by Krogdahl et al. (2015) who stated that plant-based ingredients with fiber, phytosterol, phytoestrogen, and saponin compound impacted cholesterol and bile salt absorption. Bile salt takes place indigestion and lipid digestibility. When the bile salt synthesis went lower, the lipid digestibility decreased as well. Bile salt also works in cholesterol and toxin excretion process, such as bilirubin (Romano et al., 2020).

The energy digestibility in CSP20 was higher than CSP0, CSP10, and CSP30. The increase of energy is related to the fish's ability to utilize nonprotein energy sources, such as carbohydrates and lipids. The energy digestibility in this study was higher than the standard determined by Halver (1989), who stated that the energy digestibility from seeds or plant-based ingredients was $70 \%$, whereas animal-based ingredients obtained $85 \%$ of energy digestibility. The elevating of feed digestibility was caused by a low crude fiber, high protein, and decrease of the antinutritional compound. Environmental factors, i.e. temperature, dissolved oxygen, and stock density, and the macronutrient in fish diet (Schrama et al., 2012; Haidar et al., 2016; Phan et al., 2019; Schrama et al., 2018) impacted energy digestibility.

Feed consumption is directly related to energy digestibility because fish eat to fulfill their energy requirement. A low energy digestibility in the fish diet showed a low energy utilization by the fish. The increase of feed consumption in CSP30 is a response towards various CSP levels in the fish diet. Feed conversion showed efficiency in feed utilization in fish growth. A lower feed conversion indicates efficient feed utilization (Fry et al., 2018). The CSP20 had a lower feed conversion compared to the CSP0, CSP10, CSP30, SBM20, and SBM30. It was implied that the experimental diet in CSP20 was easier to digest compared to the other treatments so that the nutrient could be utilized and digested efficiently. The feed conversion in CSP30 was higher than the other treatments. It was assumed that the experimental diet in CSP30 was barely digested and it led to the low nutrient absorption that would be used in daily metabolism. A similar case was also reported by Chovatiya et al. (2011) who explained that the increased dosage of CSL could lower the feed conversion in Roho labeo Labeo rohita. Lactic acids compound in CSP was assumed to have a certain effect on fish growth. It is in line with Castillo et al. (2014) who stated that organic acids' existence in the fish diet boost growth performance in red drum Sciaenops ocellatus juvenile because of the pepsin, trypsin, lipase, and amylase compound in the diet. A similar result was shown by Chovatiya et al. (2011) who applied CSL which contains $20.79 \%$ lactic acid and it could elevate several enzyme activities, such as protease, amylase, and lipase. The overall result stated that CSP could be utilized as a plantbased feed ingredient because of its ability to boost growth performance in tilapia.

\section{CONCLUSION}

CSP is a derivative compound from the corn starch industry with $40.27 \%$ of protein, $26.1 \%$ of lactic acid, and it is free from antinutritional compounds, such as aflatoxin, phytate acid, and 
trypsin inhibitor. The essential amino acid index presented that CSP is a qualified plant-based feed ingredient. Therefore, CSP could be an alternative plant-based ingredient of the fish diet because of its ability to elevate enzymatic activity, feed digestibility, and growth performance in tilapia. At amount of 20\% CSP inclusion was recommended in formulating the tilapia diet.

\section{ACKNOWLEDGMENT}

The authors deliver gratitude to the Ministry of Research, Tehcnology, and Higher Education and Lembaga Pengelola Dana Pendidikan (LPDP) who granted the Beasiswa Unggulan Dosen Indonesia (BUDI) Dalam Negeri 2016.

\section{REFERENCES}

[AOAC] Association of Official Analytical Chemist. 2005. Official Method of Analysis of The Association of Official Analytical of Chemist. Arlington: The Association of Official Analytical Chemist, Inc.

Adeyemo SM, Onilude AA. 2013. Enzymatic reduction of anti-nutritional factors in fermenting soybeans by Lactobacillus plantarum isolates from fermenting cereals. Nigerian Food Journal 31: 84-90.

Agbabiaka CN, Osuigwe DI. 2014. Growth response of Nile tilapia Oreochromis niloticus L. fed diets containing graded levels of anaerobically fermented palm kernel/cassava meals. Journal of Genetic and Environmental Resources Conservation 2: 302-306.

Ahmad N, Siddiqui PJA, Khan MK, Ali A, Tahir M, Akbar NU, Amin M, Attaullah M, Boneri ID. 2020. Effects of partial substitution of fishmeal by soybean mealin Nile tilapia Oreochromis niloticus diet. The Journal of Animal and Plant Sciences 30: 364-370.

Ahmad N, Siddiqui PJA, Khan MK, Akbar NU, Rashid M, Masroor R. 2018. The growth performance of juvenile yellowfin seabream Acanthopagrus arabicus fed at different feeding rates while reared in floating net cages. The Journal Animal and Plant Sciences 28: 1014-1020.

Al-Thobaiti A, Al-Ghanima K, Ahmeda Z, Sulimana EM, Mahboob S. 2018. Impact of replacing fish meal by a mixture of different plant protein sources on the growth performance in Nile tilapia Oreochromis niloticus L. diets. Brazilian Journal of Biology 78: 525-534.
Ayadi FY, Muthukumarappan K, Rosentrater KA, Brown ML. 2011. Twin-screw extrusion processing of rainbow trout Oncorhynchus mykiss feeds using various levels of corn-based distillers dried grains with solubles (DDGS). Cereal Chemistry 88: 363-374.

Azizi-Shotorkhoft A, Sharifi A, Mirmohammadi D, Baluch-Gharaei H, Rezaei J. 2015. Effects of feeding different levels of corn steep liquor on the performance of lipidtening lambs. Journal of Animal Physiology and Animal Nutrition 100: 109-117.

Bandara T. 2018. Alternative feed ingredients in aquaculture: Opportunities and challenges. Journal of Entomology and Zoology Studies 6: 3087-3094.

Bergmeyer HU, Grassi M. 1983. Methods of Enzymatic Analysis, Volume 2. Weinheim (DE): Verlag Chemie.

Bernfield P. 1955. Amylase $\alpha$ and $\beta$ in: Methods in enzymology. New York (US): Academic Press.

Bonvini E, Bonaldo A, Mandrioli L, Sirri R, Dondi F, Bianco C, Fontanillas R, Mongile F, Gatta PP, Parma L. 2018a. Effects of feeding low fishmeal diets with increasing soybean meal levels on growth, gut histology and plasma biochemistry of sea bass. Animal 12: 923-930.

Bonvini E, Bonaldo A, Parma L. 2018b. Feeding European sea bass with increasing dietary fibre levels: Impact on growth, blood biochemistry, gut histology, gut evacuation. Aquaculture 494: 1-9.

Bu X, Lian X, Zhang Y, Chen F, Tang B, Ge X, Yang Y. 2017. Effects of replacing fish meal with corn gluten meal on growth, feed utilization, nitrogen and phosphorus excretion and IGF-I gene expression of juvenile Pseudobagrus ussuriensis. Aquaculture Research 49: 977-987.

Bunda MGB, Tumbokon BLM, Serrano AE. 2015. Composition, chemical score (CS) and essential amino acid index (EAAI) of the crinkle grass Rhizoclonium sp. as ingredient for aquafeeds. Aquaculture, Aquarium, Conservation \& Legislation International Journal of the Bioflux Society 8: 411-420.

Caruso G. 2015. Use of plant products as candidate fish meal substitutes: an emerging issue in aquaculture productions. Fisheries and Aquaculture Journal 6: 1-3.

Carvalho RAPLF, Ota RH, Kadry VO, Tacon AGJ, Lemos D. 2016. Apparent digestibility of 
protein, energy and amino acids of six protein sources included at three levels in diets for juvenile white shrimp Litopenaeus vannamei reared in high performance conditions. Aquaculture 465: 223-234.

Castillo S, Rosales M, Pohlenz C, Gatlin DM. 2014. Effects of organic acids on growth performance and digestive enzyme activities of juvenile red drum Sciaenops ocellatus. Aquaculture 433: 6-12.

Chamchuen P, Pratoomchat B, Engkakul A, Kovitvadhi U, Rungruangsak-Torrissen K. 2014. Development of enzymes and in vitro digestibility during metamorphosis and molting of blue swimming crab Portunus pelagicus. Journal of Marine Biology 2014: $1-12$.

Chatvijitkul S, Davis DA, Lim CE. 2016. Lipid extracted distillers dried grains with solubles (LE-DDGS) as a partial replacement for soybean meal in hybrid tilapia (Oreochromis niloticus $\times$ O. aureus) diets. Aquaculture 459: 131-136.

ChovatiyaSG,BhattSS, ShahAR.2011.Evaluation of corn steep liquor as a supplementary feed for Labeo rohita (Ham.) fingerlings. Journal of Aquaculture International 19: 1-12.

Collins SS, Overland M, Skrede A, Drew MD. 2013. Effect of plant protein sources on growth rate in salmonids: Meta-analysis of dietary inclusion of soybean, pea and canola/rapeseed meals and protein concentrates. Aquaculture 400-401: 85-100.

Coloso RM. 2014. Feed formulation for sustainable aquaculture. Proceedings of International Workshop on Resource Enhancement and Sustainable Aquaculture Practices in Southeast Asia 2014. hal 223-230.

Daga A, Horn MB, Kottwitz LBM, Farina LO. 2015. Bromatological and mycotoxin analysis on soybean meal before and after the industrial process of micronization. Ciencia Rural 45: 1336-1341.

Dawood MAO, Koshio S, Ishikawa M, Yokoyama S. 2015. Effects of partial substitution of fish meal by soybean meal with or without heatkilled Lactobacillus plantarum (LP20) on growth performance, digestibility, and immune response of Amberjack, Seriola dumerili juveniles. BioMed Research International 2015: 1-15

Erlanger BF, Kokorsky N, Cohen W. 1961. The preparation and properties of two new chromogenic substrates of trypsin. Archives of Biochemistry and Biophysics 96: 271-278.
Eys JE. 2012. Manual of Quality Analyses for Soybean Products in the Feed Industry. $2^{\text {nd }}$ Edition. US Soybean Export Council. France.

FAO GLOBEFISH. 2017. A Quarterly update on World Seafood Markets. Rome [IT]: FAO. 70 hlm.

Fry JP, Mailloux NA, Love DC, Milli MC, Cao L. 2018. Feed conversion efficiency in aquaculture: do we measure it correctly? Environmental Research Letters 13: 024017.

Haidar MN, Petie M, Heinsbroek LTN, Verreth JAJ, Schrama JW. 2016. The effect of type of carbohydrate (starch vs nonstarch polysaccharides) on nutrients digestibility, energy retention and maintenance requirements in Nile tilapia. Aquaculture 463: 241-247.

Halver JE. 1989. Fish Nutrition. Academic Press, Inc. California. hal 113-149.

Hamidah MN, Rianingsih L, Romadhon. 2019. antibacterial activity of lactic acid bacteria isolates from peda with different types of fish against $E$. coli and $S$. aureus. Jurnal Ilmu dan Teknologi Perikanan 1: 11-21.

Herath SS, Haga Y, Satoh S. 2016. Effects of longterm feeding of corn co-product-based diets on growth, fillet color, and lipidty acid and amino acid composition of Nile tilapia, Oreochromis niloticus. Aquaculture 464: 205-212.

[IAFFD] International Aquaculture Feed Formulation Database. 2020. Feed Ingredient Composition Database v6.0. [diakses 2020 Des 20]. https://www.iaffd.com/feed.html?v=6.0

Kim KW, Moniruzzaman M, Kim KD, Han HS, Yun H, Lee S, Bai SC. 2016. Effects of dietary protein levels on growth performance and body composition of juvenile parrot fish, Oplegnathus fasciatus. International Aquaculture Research 8: 239-245

Kirimi JG, Musalia LM, Magana A, Munguti JM. 2020. Protein quality of rations for Nile tilapia Oreochromis niloticus containing oilseed meals. Journal of Agricultural Science 12: 82-91.

Koch JF, Rawles SD, Webster CD, Cummins V, Kobayashi Y, Thompson KR, Gannam AL, Twibell, RG, Hyde NM. 2016. Optimizing fish meal-free commercial diets for Nile tilapia, Oreochromis niloticus. Aquaculture 452: 357366.

Krogdahl A, Gajardo K, Kortner TM, Penn M, Gu M, Berge GM, Bakke AM. 2015. Soya saponins induce enteritis in Atlantic salmon Salmo salar L. Journal of Agricultural and Food Chemistry 63: 3887-3902.

Li X, Xu W, Yang J, Zhao H, Xin H, Zhang Y. 
2016. Effect of different levels of corn steep liquor addition on fermentation characteristics and aerobic stability of fresh rice straw silage. Animal Nutrition 4: 345-350.

Li X, Cui W, Leng X. 2015. Citric acid substituted the inclusion of inorganic phosphorus in diet of rainbow trout Oncorhynchus mykiss. Aquaculture Research 48: 1089-1098.

Lima VCO, Piuvezam G, Maciel BLL, Morais AHA. 2019. Trypsin inhibitors: promising candidate satietogenic proteins as complementary treatment for obesity and metabolic disorders? Journal of Enzyme Inhibition and Medicinal Chemistry 34: 405419.

Linfield WM, Barangkas RA, Sivieri L, Serosta S, Stevenson RW. 1984. Enzymatic lipid and synthesis. JAOCS 18: 78-87.

Liu CH, Shiu YL, Hsu JL. 2011. Purification and characterization of trypsin from the pyloric ceca of orange-spotted grouper, Epinephelus coioides. Fish Physiology and Biochemistry 38: 837-848.

Magalhaes R, Coutinho F, Pousao-Ferreira P, Aires T, Oliva-Teles A, Peres H. 2015. Corn distiller's dried grains with solubles: Apparent digestibility and digestive enzymes activities in European seabass Dicentrarchus labrax and meagre Argyrosomus regius. Aquaculture 443: 90-97.

Manullang Y, Santoso L, Tarsim. 2018. The effect of substitution of fish meal with patin fish head meal Pangasius sp. on the growth of catfish Clarias sp.. Jurnal Akuakultur Rawa Indonesia 6: 129-140.

Marquez L, Robles R, Morales GA, Moyano FJ. 2012. Gut $\mathrm{pH}$ as a limiting factor for digestive proteolysis in cultured juveniles of the gilthead sea bream Sparus aurata. Fish Physiology and Biochemistry 38: 859-869.

Mmanda FP, Lindberg JE, Halden AN, Mtolera MSP, Kitula R, Lundh T. 2020. Digestibility of local feed ingredients in tilapia Oreochromis niloticus juveniles, determined on faeces collected by siphoning or stripping. Fishes 5: $1-11$.

Mohseni M, Pourkazemi M, Hosseni MR, Hassani MHS, Bai SC. 2013. Effects of the dietary protein levels and the protein to energy ratio in sub-yearling Persian sturgeon, Acipenser persicus (Borodin). Aquaculture Research 44: 378-387.

Moraes G, Almeida LC. 2020. Nutrition and functional aspect of digestion in fish. In:
Baldisserotto B, Urbinati EC, Cyrino JEP, editor. Biology and Physiology of Freshwater Neotropical Fish. Academic Press. London. page 251-271.

Nandakumar S, Ambasankar K, Ali SSR, Syamadayal J, Vasagam K. 2017. Replacement of fish meal with corn gluten meal in feeds for Asian seabass Lates calcarifer. Aquaculture International 25: 1495-1505.

Ni Z, Ma A, Liu F, Zhu X. 2017. Optimization of nutritional factors for nisin yield improvement by lactococcus lactis E15 using corn steep liquor powder as nitrogen source. Advance in Biotechnology \& Microbiology 2: 1-13.

Nosworthy MG, House JD. 2017. Factors influencing the quality of dietary proteins: implications for pulses. Cereal Chemistry 94: 49-57.

[NRC] National Research Council. 2011. Nutrient Requirement of Fish and Shrimp. National Academy Press, Washington DC.USA.

Obirikorang KA, Amisah S, Fialor SC, Skov PV. 2015. Effects of dietary inclusions of oilseed meals on physical characteristics and feed intake of diets for the Nile tilapia, Oreochromis niloticus. Aquaculture Report 1: 43-49.

Ogello EO, Munguti JM, Sakakura Y, Hagiwara. 2014. Complete replacement of fish meal in the diet of Nile tilapia Oreochromis niloticus L. grow-out with alternative protein sources. A review. International Journal of Advanced Research 2: 962-978.

Pandey G. 2013. Feed formulation and feeding technology for fishes. International Research Journal of Pharmacy 4: 23-30.

Peisker M. 2001. Manufacturing of soy protein concentrate for animal nutrition, in Brufau J. (ed.). Feed manufacturing in the Mediterranean region. Improving safety: From feed to food. Ciheam. Zaragoza. hal 103-107.

Phan LTT, Groota R, Konnerta GDP, Masagounderb K, Figueiredo-Silvab AC, Glencrossc BD, Schrama JW. 2019. Differences in energy utilisation efficiencies of digestible macronutrients in common carp Cyprinus carpio and barramundi Lates calcarifer. Aquaculture 511: 734238.

Potki N, Falahatkar B, Alizadeh A. 2018. Growth, hematological and biochemical indices of common carp Cyprinus carpio fed diets containing corn gluten meal. Aquaculture International 26: 1573-1586.

Prabu E, Rajagopalsamy CBT, Ahilan B, Jeevagan IJMA, Renuhadevi M. 2019. 
Tilapia-an excellent candidate species for world aquaculture: A review. Annual Research \& Review in Biology 31: 1-14

Rahimi ZS, Modirsanei M, Mansoori B, Rezaeian M, Farkhoy M, Honarzad J. 2017. The effect of enzymatic pre-treatment of corn or soybean meal on their phytate content under different in vitro conditions. Iranian Journal of Veterinary Medicine 11: 323-334.

Ravindran V, Abdollahi MR, Bootwalla SM. 2014. Nutrient analysis, metabolizable energy, and digestible amino acids of soybean meals of different origins for broilers. Poultry Science 93: 1-11.

Roger T, Leopold TN, Funtong MCM. 2015. Nutritional properties and antinutritional factors of corn paste (Kutukutu) fermented by different strains of lactic acid bacteria. International Journal of Food Science 1: 1-13.

Romano N, Kumar V, Yang G, Kajbaf K, Rubio MB, Overturf K, Brezas A, Hardy R. 2020. Bile acid metabolism in fish: disturbances caused by fishmeal alternatives and some mitigating effects from dietary bile inclusion. Reviews in Aquaculture 12: 1792-1817.

Ronnestad I, Yufera M, Ueberschar B, Ribeiro L, Saele O, Boglione C. 2013. Feeding behaviour and digestive physiology in larval fish: current knowledge, and gaps and bottlenecks in research. Review in Aquaculture 5: S59-S58.

Rungruangsak-Torrissen K, Manoonpong P. 2019. Neural computational model growth estimate: A model for studying living resources through digestive efficiency. PLOS ONE 14: e0223740.

Saez PJ, Abdel-Aal ESM, Bureau DP. 2014. Feeding increasing levels of corn gluten meal induces suboptimal muscle pigmentation of rainbow trout Oncorhynchus mykiss. Aquaculture Research 47: 1972-1983.

Schrama JW, Saravanan S, Geurden I, Heinsbroek LTN, Kaushik SJ, Verreth JAJ. 2012. Dietary nutrient composition affects digestible energy utilisation for growth: a study on Nile tilapia Oreochromis niloticus and a literature comparison across fish species. British Journal of Nutrition 108: 277-289.

Schrama JW, Haidar MN, Geurden I, Heinsbroek LTN, Kaushik SJ. 2018. Energy efficiency of digestible protein, lipid and carbohydrate utilisation for growth in rainbow trout and Nile tilapia. British Journal of Nutrition 119: 782-791.

Sekali M, Mlambl V, Marume U, Mathuthu M.
2020. Replacement of soybean meal with heat-treated canola meal in finishing diets of meatmaster lambs: physiological and meat quality responses. Journal Animals 10: 1735.

Setyawan AA, Sukanto, Widyastuti E. 2014. Populasi bakteri asam laktat pada budidaya ikan nila yang diberi pakan fermentasi limbah pertanian dengan suplemen enceng gondok dan probiotik. SCRIPTA BIOLOGICA 1: 91-95.

Sharma BB, Saha RK, Saha H. 2014. Effects of feeding detoxified rubber seed meal on growth performance and haematological indices of Labeo rohita (Hamilton) fingerlings. Animal Feed Science Technology 193: 84-92.

Smiglak-Krajewska M. 2020. Determinants of the selection of raw materials used in animal feed production. Annals of The Polish Association of Agricultural and Agribusiness Economists XXII: 191-199.

Sukhanandi SM, Bhatt SS. 2016. Corn steep liquor with lysine and chelated minerals as supplementary feed for Labeo rohita fingerlings. International Journal of Fisheries and Aquatic Studies 4: 180-187.

Sun S, Li H, Chen J, Qian Q. 2017. Lactic acid: no longer an inert and end-product of glycolysis. Physiology 32: 453-463.

Suprayudi MA, Edriani G, Ekasari J. 2012. Quality evaluation of fermented products of various local agroindustrials by-products: the effect on digestibility and growth performance of common carp juvenile. Jurnal Akuakultur Indonesia 11: 1-10.

Suprayudi MA, Faisal B, Setiawati M. 2013. The growth of red tilapia fed on organic-selenium supplemented diet. Jurnal Akuakultur Indonesia 12: 48-53.

Suprayudi MA, Yaniharto D, Priyoutomo N, Kurnianto A, Ekasari J, Jusadi D, Haga Y. 2015. Evaluation of practical diets containing high levels of corn distillers dried grains with soluble on red tilapia floating net cage production performance. Pakistan Journal of Nutrition 14: 708-711.

Takeuchi T. 1988. Laboratory work-chemical evaluation of dietary nutrient. In Watanabe, $\mathrm{T}$ (ed). Fish nutrition and mariculture. Departement of Aquatic Bioscience, Tokyo University of Fisheries. hal 179-233.

Tan JP, Jahim JM, Wu TY, Harun S, Mumtaz T. 2016. Use of corn steep liquor as an economical nitrogen source for biosuccinic acid production 
by Actinobacillus succinogenes. IOP Conference Series: Earth and Environmental Science 36: 1-5.

Tereos Indonesia, PT. 2016. Corn wet milling industry. Cilegon Banten. Indonesia.

Thongprajukaew K, Rodjaroen S, Tantikitti C, Kovitvadhi U. 2015. Physicochemical modifications of dietary palm kernel meal affect growth and feed utilization of Nile tilapia Oreochromis niloticus. Animal Feed Science and Technology 202: 90-99.

Trosvik KA, Rawles SD, Thompson KR, Metts LA, Gannam A, Twibell R, Webster CD. 2012. Growth and body composition of Nile tilapia, Oreochromis niloticus, fry fed organic diets containing yeast extract and soybean meal as replacements for fish meal, with and without supplemental lysine and methionine. Journal of the World Aquaculture Society 43: 635647.

Wafar RJ, Yakubu B, Lalabe BC. 2017. Effect of feeding raw kapok Ceiba pentandra seed meal on the growth performance, nutrient digestibility, carcass and organ weights of weaner rabbits. Asian Research Journal of Agriculture 5: 1-8.

Watanabe T. 1988. Fish nutrition and mariculture, JICA textbook, the general aquaculture course, Departement of Aquatic Bioscience, Tokyo University of Fisheries. Tokyo. 233 hal.
Welker TL, Lim C, Klesius P, Liu K. 2014. Evaluation of distiller's dried grains with solubles from different grain sources as dietary protein for hybrid tilapia, Oreochromis niloticus () $\times$ Oreochromis aureus (さ). Jornal of the World Aquaculture Society 45: 625-637.

Worthington V. 1993. Worthington Enzyme Manual. Enzymes and Related Biochemicals. New Jersey (US): Worthington Chemical.

$\mathrm{Xu} \mathrm{H}, \mathrm{Mu}$ Y, Zhang Y, Li J, Liang M, Zheng K, Wei Y. 2016. Graded levels of fish protein hydrolysate in high plant diets for turbot Scophthalmus maximus: effects on growth

Yue GH, Lin HR, Li JL. 2016. Tilapia is the fish for next-generation aquaculture. International Journal of Marine Science and Ocean Technology 3: 11-13.

Yulintine, Harris E, Jusadi D, Affandi R, Alimuddin. 2012. Development of digestive enzime activity in climbing perch Anabas testudineus Bloch. Bionatura-Jurnal Ilmuilmu Hayati dan Fisik 14: 59-67.

Zhang C, Rahimnejad S, Wang Y, Lu K, Song K, Wang L, Mai K. 2018. Substituting fish meal with soybean meal in diets for Japanese seabass Lateolabrax japonicus: Effects on growth, digestive enzymes activity, gut histology, and expression of gut inflammatory and transporter genes. Aquaculture 483: 173-182. 